\title{
Ms 点による冷間ダイス鋼における焼入性の評価
}

\author{
広瀬之彦*，山本誠司**，板倉邦輔***
}

\section{Evaluation of Hardenability of Cold Die Steel by Ms Temperature}

Nobuhiko Hirose, Seiji Yamamoto and Kunisuke Itakura

\section{Synopsis}

The precipitation behavior of carbides and the shifting tendency of the Ms temperatures in the three kinds of cold die steel (JIS SKD 1, SKD 11 and SKD 12) under various cooling conditions from austenitizing temperature has been investigated using a scanning electron microscope(SEM) and a dilatometer.

As a result of the slower cooling from the austenitizing temperature, the reaction of carbide precipitation occurs at grain boundaries, and then, within the grain of the prior austenite. The Ms temperature in each kind of steel shifts toward the higher temperature side following a decrease in the cooling rate from the austenitizing temperature.

In this study, the relationship between the precipitation of the carbides and $\mathrm{Ms}$ temperature in the cold die steel has been clarified and finally, the evaluation of hardenability due to carbide precipitation is discussed using these measured Ms temperature data as the index.

\section{1. 緒}

焼入冷却速度が小さくなると冷却途中の1000 $\sim 850^{\circ} \mathrm{C}$ の高温部で炭化物が析出する現象は, 当 初, 高速度工具鋼 ${ }^{1)}$ で見出されて以来，析出条件， 析出に及ぼす合金元素の影響など多くの研究結 果2)-6)の報告がある.また, 熱間ダイス鋼では炭化 物析出とペイナイト変態挙動や機械的性質 ${ }^{7) ~ 11) ~}$ との関連より調へられ，さらに最近では構造用の

1993年 4 月11日受付

"松江工業高等専門学校機械工学科, 工博

**松江工業高等専門学校機械工学科

***松江工業高等専門学校電子制御工学科
マルテンサイト系ステンレス鋼12),13)でも問題に されている．しかし，同様の現象は冷間ダイス鋼 でも起こると解説14)されているが，詳細な報告は 少ないようである15).

高速度工具鋼やタイス鋼は本来焼入性が良好で あるが, 冷却速度の減少に伴う炭化物析出は焼入 れあるいは焼戻し硬さや䩗性の低下をきたすこと から，構造用鋼などの焼入性とは異なる炭化物焼 入性とも称されている(14).この炭化物析出に起因 する焼入性の評価については，通常のジョミニー 試験では差が得られないために，改良型ジョミニ

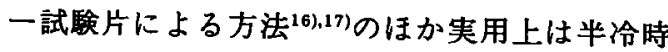
間と硬さの関係によるいわゆる半冷曲線(4)によっ て評価されているようである。しかし，冷却速度 
と硬さの変化で表す半冷曲線を求める場合，焼入 れまたは低温焼戻し硬さについては残留オーステ ナイト $\left(\gamma_{\mathrm{R}}\right)$ の影響が大きく，ミクロ組織との対 応が必要となる．また，高温焼戻し後の硬さでは， $\gamma_{\mathrm{R}}$ の分解の程度のほか, 二次硬化のピーク硬さが 得られる焼戻し温度は炭化物が析出すると低温側 にずれることが予想され，一律の温度での焼戻し では正確さを欠くものと考之られる.いずれにし ても，半冷曲線の作成は容易ではない。

一方，鋼のマルテンサイト生成開始温度である Ms 点は, 変態前のオーステナイトの炭素およU゙ 合金元素濃度によって変化することが知られてい $3^{18)}$. このことより, 上記の焼入冷却途中での炭化 物析出はオーステナイトの元素濃度の低下とな $\eta, \mathrm{Ms}$ 点の高温側への移行が推察される. 従っ て，逆にMs点の変化を知ることによって炭化物 の析出状況が把握でき,さらには炭化物析出に関 連する焼入性の評価もできると思われる。また， オーステナイトの組成に对応する Ms 点によれ ば，種々の要因がからむ硬さによる評洒と比較し て，焼入性のより正確なかつ微妙な判定も可能で あると考える。

以上の観点より, 本研究では, 炭化物析出に関 する報告が少ない冷間タイス鋼について，半冷曲
線により焼入性が異なるとされている 3 鋼種を選 び，まず，焼入冷却速度の滅少に伴う炭化物の析 出現象と Ms 点との関連について調べ,さらに $\mathrm{Ms}$ 点による焼入性の評価の可能性について検討 した. また，マルテンサイト生成温度はマルテン サイトの形態にも影響を及ぼすとされており 19), 炭化物析出, Ms 点の挙動およびマルテンサイト の形態との関連についても調べた.

\section{2. 実 験 方 法}

供試材は丸棒状で焼なまし状態の JIS 3 鋼種 で, その化学組成を Table 1 に示す.これら 3 鋼種

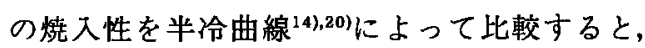
SKD 11が最も良好で，ついでSKD 12，SKD 1の 順となる。

Ms 点は熱膨張計によって求めたが, 試験片は 供試材より温度追従性をよくするために $\phi 5 \times 15$ $\ell \mathrm{mm}$ で肉厚 $0.5 \mathrm{~mm}$ のパイプ状 ${ }^{15}$ に機械加工 し，また，温度測定には $\phi 0.1 \mathrm{~mm}$ の PR 熱電对を 分離し, 試験片の $1 / 2 \ell て ゙$ 軸対称にスポット溶接す

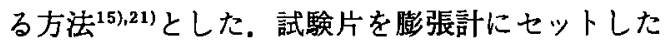
のち，赤外線炉を用いて真空中で Fig.1のように 一定の速度で $1050^{\circ} \mathrm{C}$ るいは $980^{\circ} \mathrm{C} に$ 加熱し15

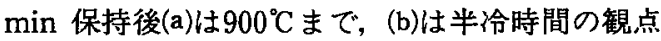

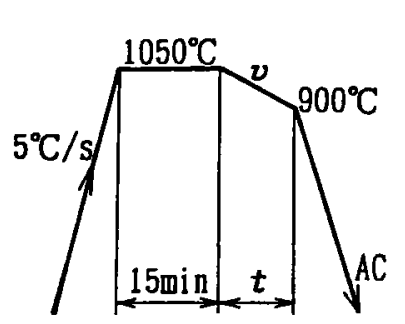
(a) $v$ : Cooling rate
: $0.1 \sim 13\left({ }^{\circ} \mathrm{C} / \mathrm{s}\right)$
[ $t$ :Cooling time(s)]

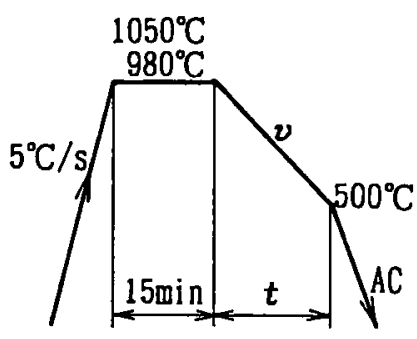
(b) $v$ : Cooling rate $: 30 \sim 240\left({ }^{\circ} \mathrm{C} / \mathrm{min}\right)$
[ $t:$ Cooling time(min)!]

Fig. 1. Conditions of heat treatment.

Table 1. Chemical composition of steels used.

\begin{tabular}{c|cccccccc}
\hline Steel & C & Si & Mn & P & S & Cr & Mo & V \\
\hline SKD 1 & 2.10 & 0.27 & 0.49 & 0.018 & 0.004 & 12.50 & - & - \\
SKD 11 & 1.47 & 0.30 & 0.39 & 0.019 & 0.005 & 11.93 & 0.84 & 0.23 \\
SKD 12 & 0.96 & 0.28 & 0.65 & 0.018 & 0.001 & 5.14 & 1.04 & 0.21 \\
\hline
\end{tabular}


から $500^{\circ} \mathrm{C}$ までの椧却速度を変えて処理した。 な お, $1050(980){ }^{\circ} \mathrm{C} \times 15 \mathrm{~min}$ 加熱後，炉を開放し放 冾する処理 $(\mathrm{AC})$ も行ったが, この時の平均冷却速 度は $1050 \sim 900^{\circ} \mathrm{C} て ゙$ 約 $13^{\circ} \mathrm{C} / \mathrm{s}, 1050 \sim 500^{\circ} \mathrm{C}$ の場合 が約 $4{ }^{\circ} \mathrm{C} / \mathrm{s}$ であった.

熱処理した試料についてビッカース硬さ (HV) を測定したが，試料が薄肉で試験荷重が9.807N (1kgf)で局部的な值となるため, 別に $\phi 15 \times 10 \mathrm{t} \mathrm{mm}$ の試料を処理してロックウェル硬さ (HRC) も測 定した.この場合の加熱はソルト中で行い，冷却 条件は試料の表面と中心部での相違を小さくする ために連続冷却はせず，焼入温度から $900^{\circ} \mathrm{C}$ に保っ たソルトに浸漬し， 5，10，30 minの一定時間保 持後油冷の処理とした．また，比較のため焼入温 度から直接油冷する処理も行い，その後， 100 600 $\mathrm{C} て ゙ の$ 繰返し焼戻しをした。

以上，熱処理したすへてての試料について研摩， 䋀食後, 光学顕微鏡と走查型電子顕微鏡 (SEM) に よって組織を観察した. なお，腐食は $5 \%$ ナイター ルで行ったが，マルテンサイト組織の現出には， ピクリン酸一塩酸ーアルコール溶液あるいは塩化 第二鉄一塩酸一水（またはアルコール）溶液を用 いた，また，一部の条件の試料について，画像解 析装置（ルーゼックス450）を用いて SEM 写真に よる $\gamma_{\mathrm{R}}$ の面積率（\%）を測定した。

\section{3. 実 験 結 果}

\section{1 等 膨張 曲 線}

熱膨張計によって加熱・冷却中に記録した冷却 時の熱膨張曲線から Ms 点を求めたが，SKD 1で 得られた曲線の一例をFig. 2 に示す。図は 980 500 ${ }^{\circ} \mathrm{C}$ 間の冷却速度を変えて処理した場合 で，冷却時に長さの変化が極小となる温度をもっ

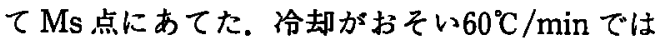
$700^{\circ} \mathrm{C}$ 付近で一部 $\mathrm{Ar}^{\prime}$ 変態によるものと思われる 変化をしているが,ささらに温度が低下した $240^{\circ} \mathrm{C}$ 付 近でマルテンサイト変態による膨張変化が認めら れ,この点を Ms 点とした, 冷却速度がさらに大き くなると $\mathrm{Ar}^{\prime}$ 変態による曲線の変化はなく，マル テンサイト変態による Ms 点のみが表れており， また，冷却速度によって Ms 点が変化しているこ ともわかる.なお，SKD 11，SKD 12については， 本実験条件の冷却速度の範囲では $\mathrm{Ar}^{\prime}$ 変態は認 められず,この点からも 3 鋼種中で SKD 1の焼入

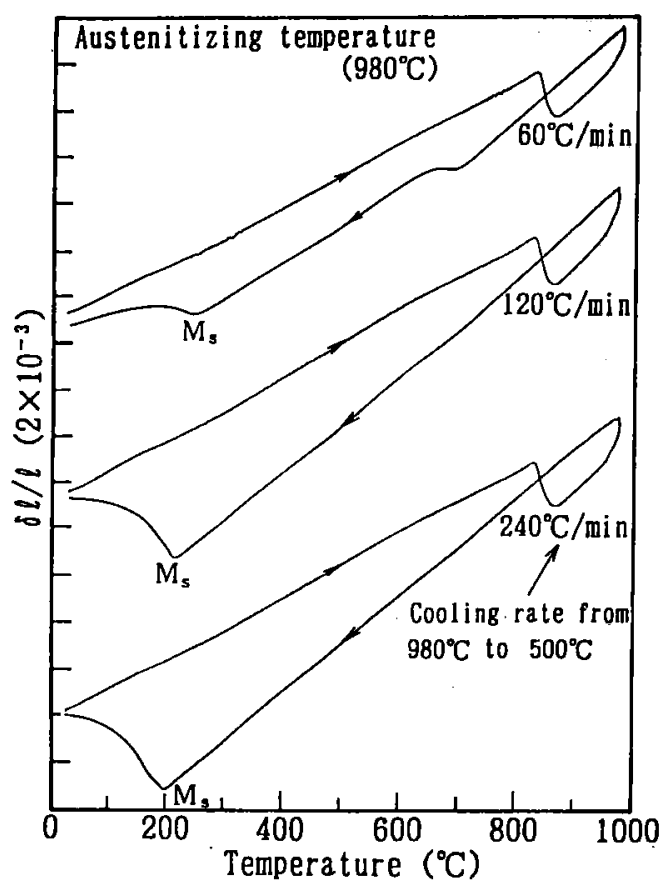

Fig. 2. Dilatometric curve during the transformation of SKD 1.

性が最小であることがうなずける。

\section{$3.2 \mathrm{Ms}$ 点について}

3 鋼種についてオーステナイト化温度1050 $900^{\circ} \mathrm{C}$ までの冷却速度を変えて処理した場合の Ms 点を求めたが, SKD 1と SKD 11の結果を Fig. 3 に示す．2 鋼種いずれも冷却速度の減少に伴い Ms 点は高温側に移行しており，冷却がおそくな るにつれて析出する炭化物が多くなり不安定さを 増したオーステナイトがより高温部でマルテンサ イト変態することがうかがえる.この Ms 点が高 温側へ移行する温度幅は SKD 11に比へて SKD 1 のほうがかなり大きくっている，なお，この傾 向は冷却速度が比較的大きい場合に顕著である。

Fig. 4 は Fig. 3 と同様のデー夕を用いて, 1050 $\sim 900^{\circ} \mathrm{C}$ 間の冷却に要した時間に对する $\mathrm{Ms}$ 点の 変化する温度幅を明示した図である。冷却時間に 対してMs 点が高温に移行する傾向が SKD 11, SKD 12, SKD 1 の順に大きくなっていることが さらに明らかである．3 鋼種における $\mathrm{Ms}$ 点の変 化傾向は，半冷曲線によって表されている焼入性 の大小とよく对応する。 


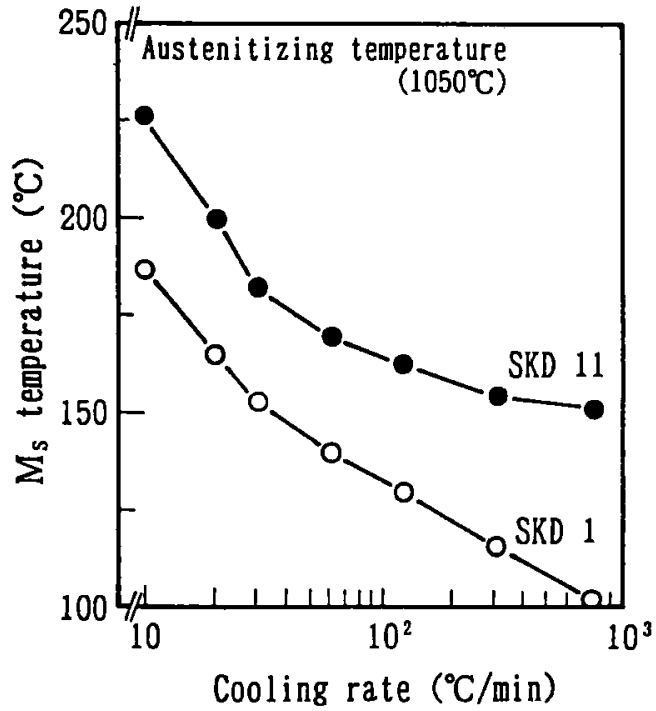

Fig. 3. Effect of cooling rate between 1050 $\sim 900^{\circ} \mathrm{C}$ on $\mathrm{Ms}$ temperature.

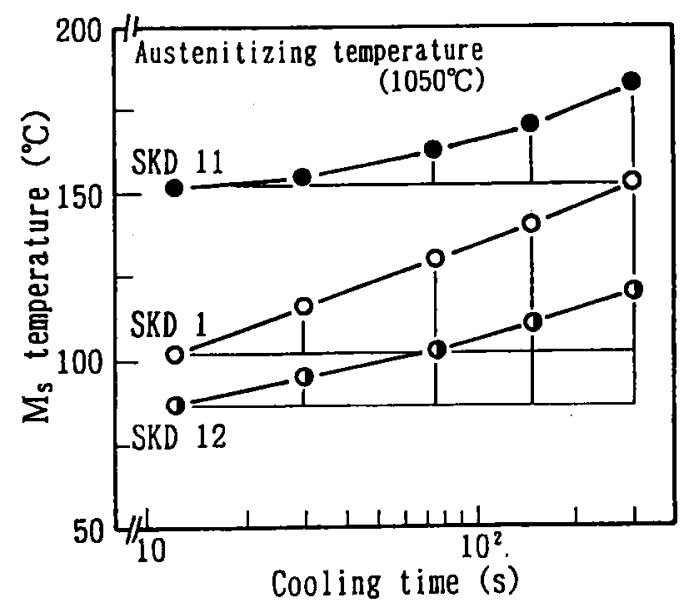

Fig. 4. Effect of time for cooling from $1050^{\circ} \mathrm{C}$ to $900^{\circ} \mathrm{C}$ on $\mathrm{Ms}$ temperature.

以上の実験は， 3 鋼種の $\mathrm{Ms}$ 点について同一の オーステナイト化温度 $\left(1050^{\circ} \mathrm{C}\right)$ によって比較し たが，実用上の焼入温度からするとSKD 1 と SKD 12に関して1 $050^{\circ} \mathrm{C}$ は高すぎる.そこで， 3 鋼 種ともJIS 表示の上限の焼入温度（SKD 11は $1050^{\circ} \mathrm{C}$, SKD 1と SKD 12 は $980^{\circ} \mathrm{C}$ )により，また， 半冷時間との比較も考虑して1050(980) 500 ${ }^{\circ} \mathrm{C}$ までの冷却速度を変えて処理した場合の Ms 点を

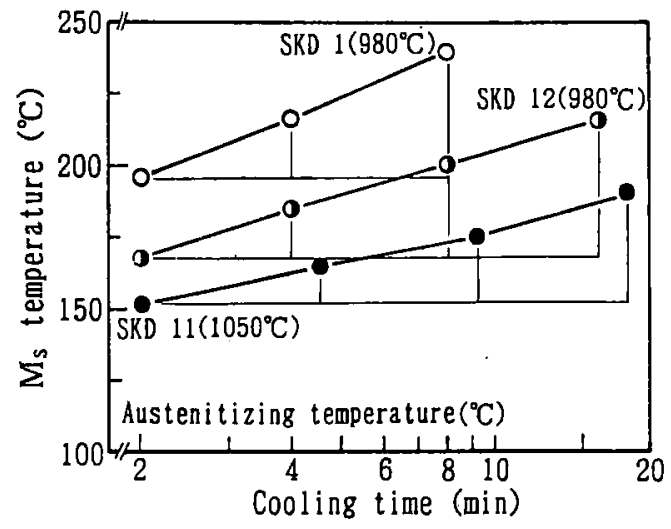

Fig. 5. Effect of time for cooling from austenitizing temperature to $500^{\circ} \mathrm{C}$ on $\mathrm{Ms}$ temperature.

調べた. その結果が Fig.5で，Fig. 4 と同様に $500^{\circ} \mathrm{C}$ までの冷却に要した時間と $\mathrm{Ms}$ 点の変化傾 向との関係を示した図である.オーステナイト化 温度が異なってもMs 点の変化傾向は Fig. 4 と同 様で, 冷却に要した時間が長くなるにつれて Ms 点は高くなっている. Ms 点の変化する温度幅に 関する 3 鋼種間での差は Fig. 4よりむしろ大き くはっきりと表れており, SKD 11, SKD 12, SKD 1 と Ms 点の高温側への移行傾向は大となってい る.

\section{3 ミク口組織について}

焼入冷却がおそくなると Ms 点は高くなること を示し，その理由として炭化物の析出によるもの であろうとしたが，その点を明らかにするためミ クロ組織について調べた.Photo.1は 1050 $\sim 900^{\circ} \mathrm{C}$ 間の冷却速度を変えて処理したSKD 11 の光学顕微鏡による組織である. 冷却速度が小さ くなるとオーステナイトの結晶粒界は非常に腐食 され易くなり，Photo.1でも(a)に比べて(b)さらに (c)とやや粒界が太くなっていることがわかる。こ の粒界の変化に従って，粒界抢よび粒内に微細な 炭化物が多くなっていることも認められ，冷却速 度の減少に伴い炭化物の析出量が増していること を示している.この傾向はSKD 1 ，SKD 12の光 学顕微鏡組織でも同様に認められた，析出炭化物 についてさらに明らかにするため SEM 組織を観 察した結果を Photo.2 に示す. Photo.2 は SKD 1 と SKD 12について, 1050 900 ${ }^{\circ}$ 間の冷却速度を 変化させた場合である，冷却がおそくなると粒界 


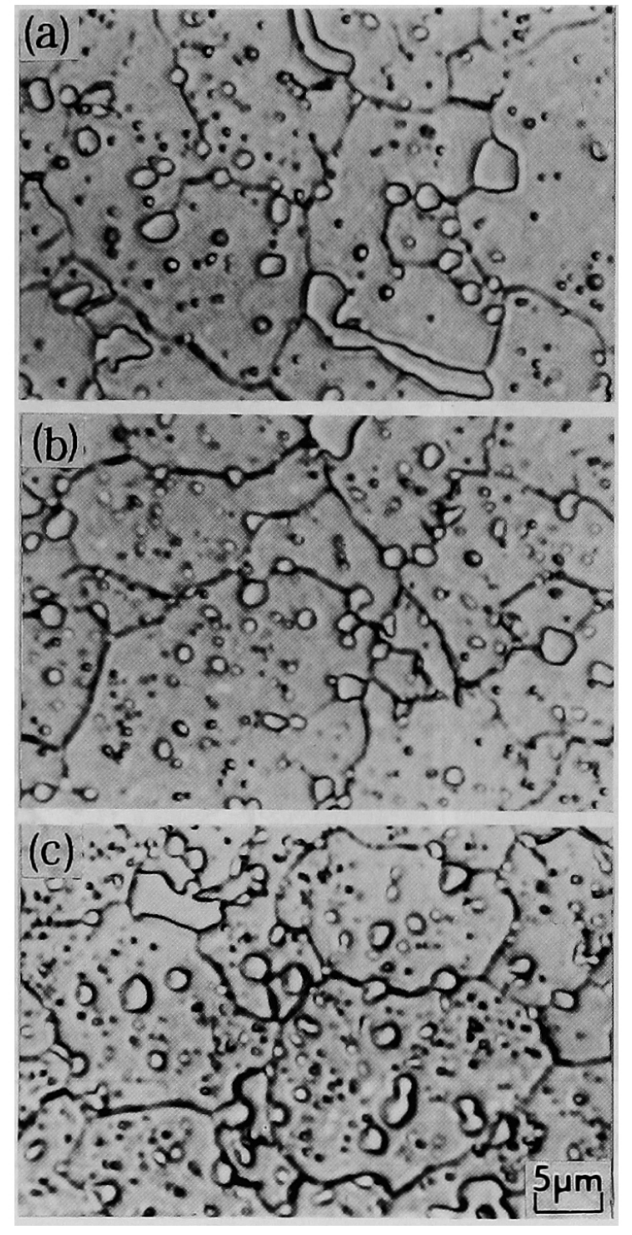

Photo. 1. Optical microstructures of SKD 11 quenched at various cooling rates between $1050 \sim 900^{\circ} \mathrm{C}$. (a) $13^{\circ} \mathrm{C} / \mathrm{s}$, (b) $5^{\circ} \mathrm{C} / \mathrm{s}$, (c) $1^{\circ} \mathrm{C} / \mathrm{s}$.

に析出したと思われる微細な炭化物が多くなり， また粒内にも析出していることがはっきりとわか る. しかし，析出炭化物の多少はわかるものの, 定量することは難しく数值的な比較はできない。 また，同様に，同一冷却速度におけるSKD 1 と SKD 12の析出炭化物量はSKD 1のほうが多いよ うであるが，定量的に比べることは困難である。 また, 析出炭化物の形㮩は粒状が主体であるが, 一部には若干細長い炭化物も認められ，これがフ イルム状といわれている炭化物と思われる。

以上，組織観察により炭化物の析出現象につい て調へた結果，炭化物の析出と Ms 点の高温への 変化傾向には非常によい对応関係があることを認

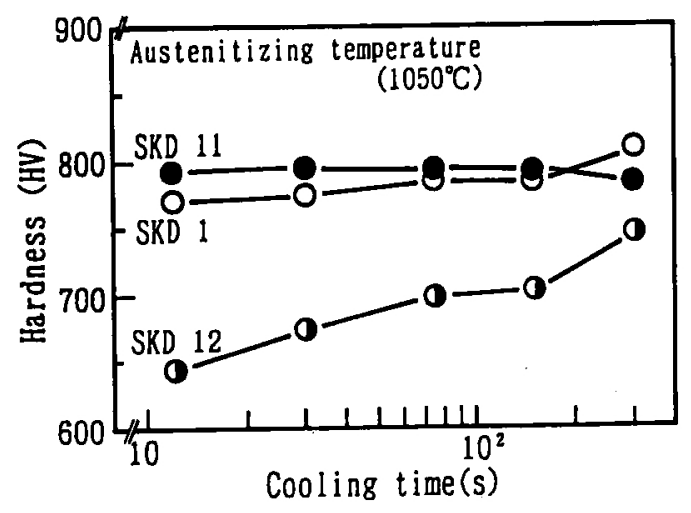

Fig. 6. Effect of time for cooling from $1050^{\circ} \mathrm{C}$ to $900^{\circ} \mathrm{C}$ on quenched hardness.

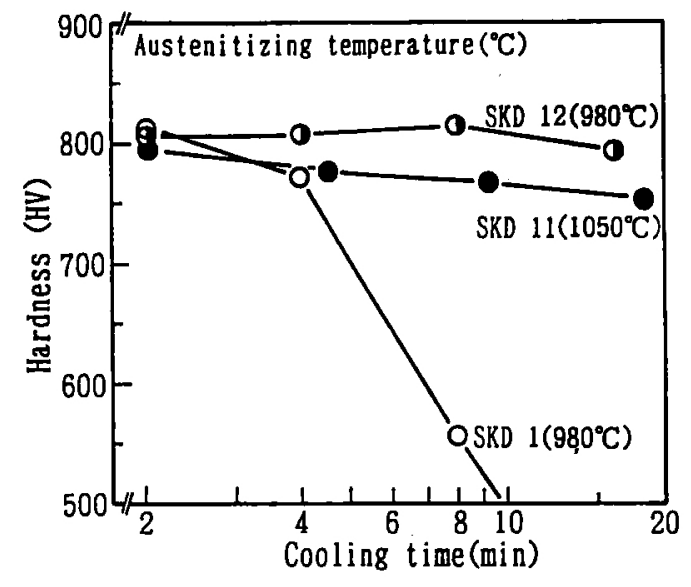

Fig. 7. Efect of time for cooling from austenitizing temperature to $500^{\circ} \mathrm{C}$ on quenched hardness.

めた。

\section{4 焼入れおよび焼戻し硬さについて}

熱膨張測定後の試料について硬さ $(\mathrm{HV})$ を測定 した. Fig. 6 は1 050〜 900 $\mathrm{C}$ 間を，Fig. 7 は 1050 (SKD 1, SKD 12は980) $500^{\circ} \mathrm{C}$ までの冷却速度を 変之た場合で，焼入状態の硬さと上記温度間の冷 却に要した時間との関係を示している.

Fig. 6 で, 冷却時間が長くなるにつれて SKD 12 では硬さがかなり上昇しており，SKD 1でもやや 增加の傾向が認められるが, SKD 11では大きな変 化はみられず，長時間側で若干低下する傾向にあ る. 冷却速度が減少し, 冷却に長時間要する条件 では炭化物の析出量は増し, 得られるマルテンサ 


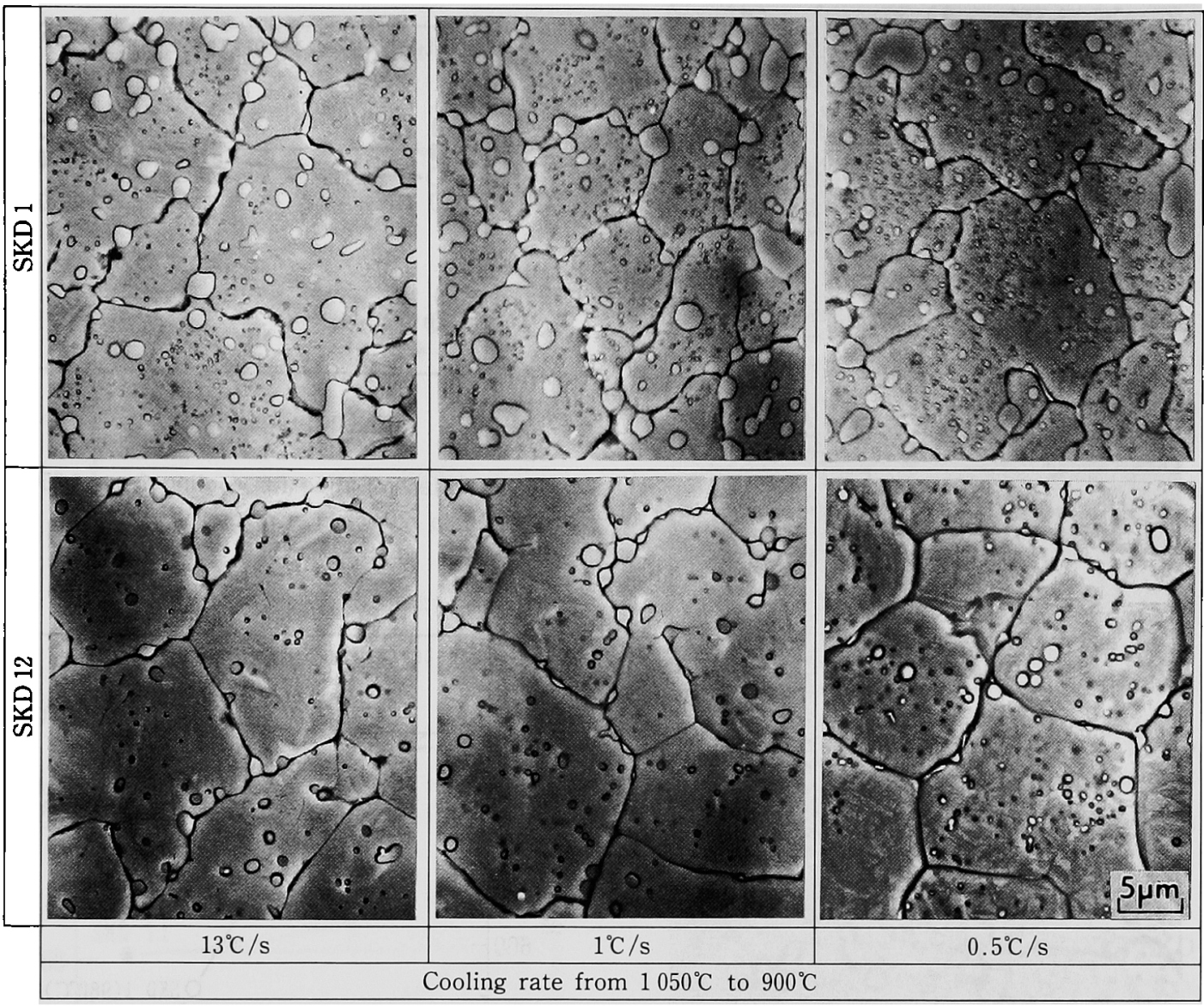

Photo.2. Scanning electron micrographs of specimens quenched at various cooling rates.

イトの硬さは低下するものと予測される.しかし， SKD 1と SKD 12の結果は逆の傾向となってお ク,これには，オーステナイト化温度が $1050^{\circ} \mathrm{C}$ と 高く $\gamma_{\mathrm{R}}$ 変化量の影響が考えられる.

Fig. 7 では, SKD 1と SKD 12のオーステナイト 化温度が $980^{\circ} \mathrm{C}$ と低くしたために $\gamma_{\mathrm{R}}$ の影響は小さ くなっていると思われる. 図によれば, SKD 11お よび SKD 12の硬さにはほとんど変化がないが, SKD 1の硬さは冷却時間の増大によって急激に低 下している．3鋼種中焼入性が最も劣るSKD 1で は，Fig. 2 でも認められたように冷却がおそくな ると冾却中にパーライトノーズにかかった結果と いえる，このように，焼入性についての差が大き い場合には焼入硬さからも焼入性の評価は可能で ある.しかし, SKD 11と SKD 12の結果にみられ
るように炭化物析出に伴う焼入性の相違を焼入硬 さの変化のみから判断することは $\gamma_{\mathrm{R}}$ などその他 の因子の影響もあり難しい。

次に, 膨張試験片とは別に $\phi 15 \times 10 \mathrm{~mm}$ の試料 について $1050^{\circ} \mathrm{C}$ からの冷却途中 $900{ }^{\circ} \mathrm{C} て ゙$ 等温保持 後, 油冷する処理をし, 焼入れおよU゙繰返し焼戻 しによる HRC を比較した. なお, 冷却時の等温保 持によるSKD 11に関する炭化物析出状況と Ms 点の変化についてはすでに報告 ${ }^{15)}$ したが, SKD 1 と SKD 12についてもSKD 11の場合のように保 持時間を長くすることにより冷却速度を小さくし た場合と同様な効果が得られることを予備実験に より確認した. Fig. 8 に $\gamma_{\mathrm{R}}$ が分解する高温部で焼 戻した場合の SKD 1 とKD 11の硬さの変化を示 す. 焼入冷却途中での等温保持による焼戻し硬さ 

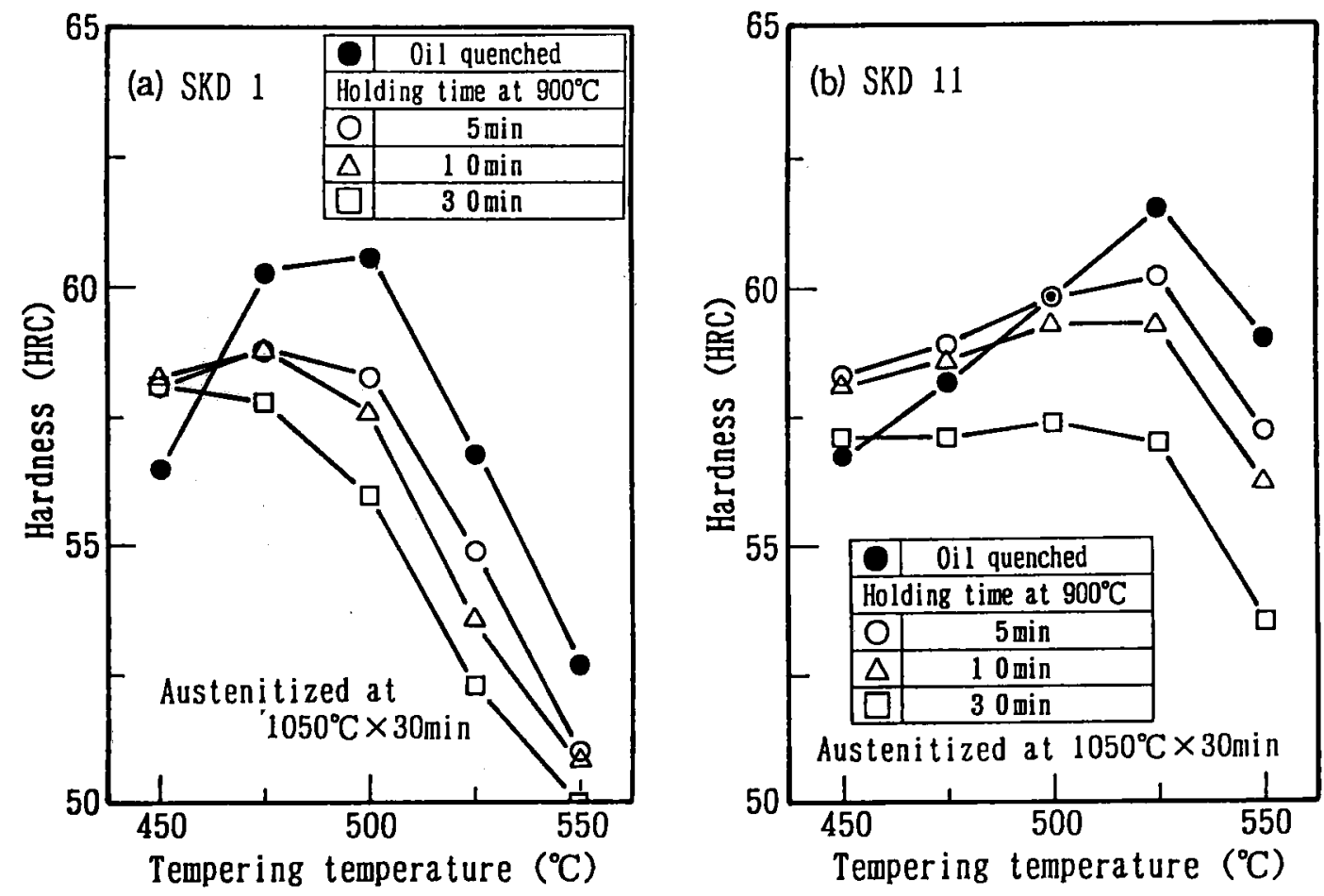

Fig. 8. Effect of isothermal holding on tempered hardness.

への影響が認められ，2 鋼種ともに保持時間を長 くするにつれて焼戻し硬さが低下することがはつ きりとかかり，保持中に炭化物が析出することが うかがえる。しかし，保持時間を長くした場合に は，焼入温度を低くした場合と同様に最高の硬さ が得られる焼戻し温度が低くなっており，同一の 焼戻し温度での硬さの比較はできない，また， SKD 1と SKD 11における油冷と30 min 保持での 硬さを比較すると, SKD 11のほうがその差が大き くなってわり, 焼戻し硬さの変化傾向と炭化物の 析出に起因する焼入性の評価とはやや異なる結果 が得られた。

\section{4. 考察}

\subsection{Ms点と組鐡に及ほす寸焼入冷却速度の影響}

焼入冷却途中での宸化物の析出は，初期には才 一ステナイトの結晶粒界に, さらに冷却速度が減 少すると粒内にも起こり, 冷却がおそくなるにつ れて析出量が增す。この炭化物の析出によってC およびその他合金元素濃度が低下することによっ て不安定となったオーステナイトからマルテンサ
イトへの変㦔温度は上昇する. 従って, Ms 点の挙 動はオーステナイトの元素濃度の変化,つまり炭 化物の析出量を的確に表しているといえる.

なお，組織観察によっても焼入冷却速度の減少 に伴って析出する炭化物が增加することは認めら れた. しかし，この析出炭化物のみの定量につい てはマトリックス鋼22)によれば可能かと思われる が, 本実験鋼種のように高Cで多量の未溶解炭化 物が存在する場合にはできない，また，析出炭化 物に未溶解炭化物を含めた定量では，析出のわず かな差は得られないものと思われる。

一方, 炭化物析出によるオーステナイトの元素 濃度の低下は Ms 点を上㫒させ,このことは, マル テンサイトの形態にも影響を及はすと考えられ

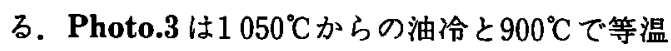
保持の処理をした場合の SKD 1と SKD 12の組織 である，2 鋼種ともに油冷での粗いマルテンサイ トが $5 \mathrm{~min}$ さらには $30 \mathrm{~min}$ 保持では著しく微細化 している.マルテンサイトの微細化に伴い $\gamma_{\mathrm{R}}$ も減 少し，その形態も細かくなっていることが認めら れる. 炭化物の析出によるマルテンサイトの微細 


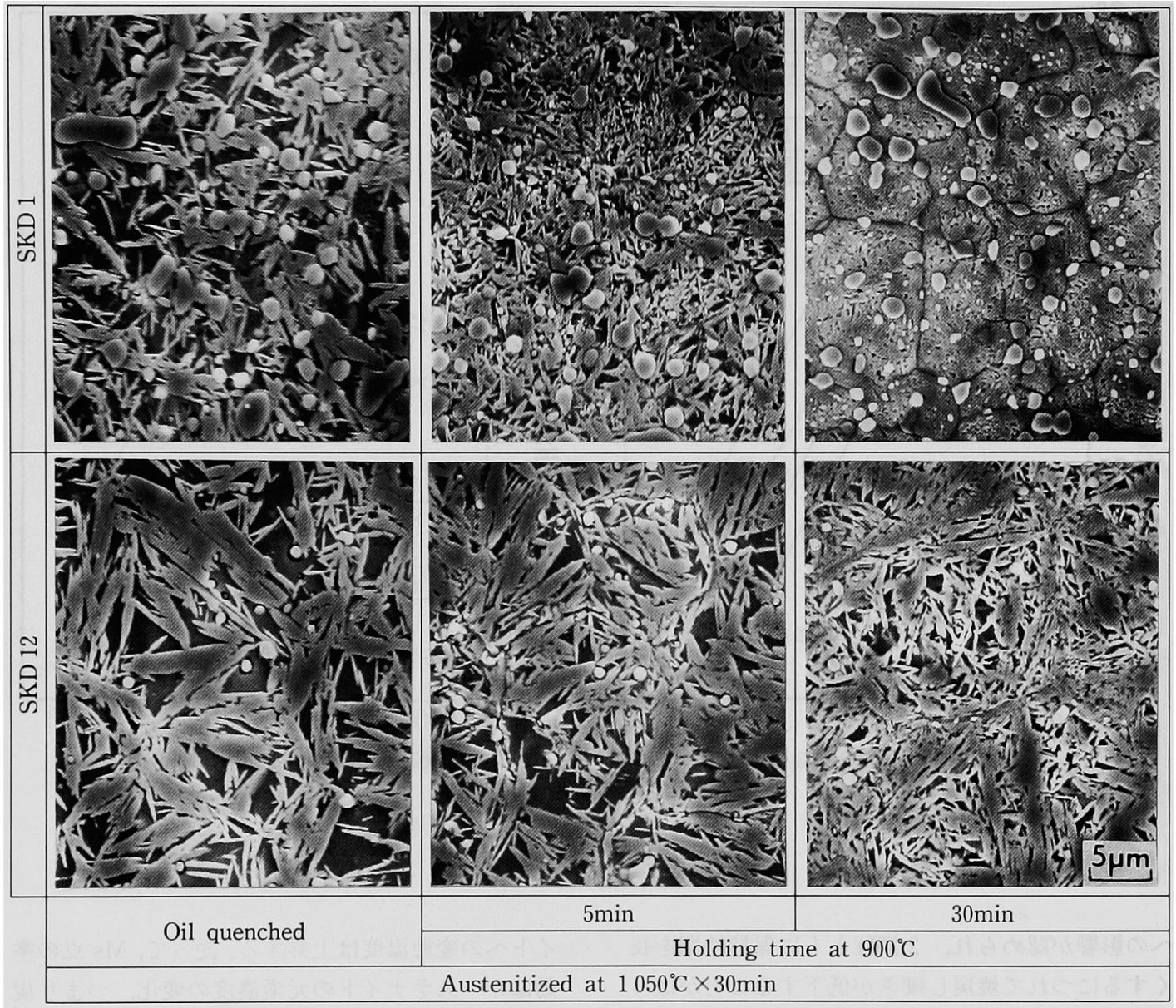

Photo. 3. Scanning electron micrographs of specimens quenched at various cooling conditions.

化は靶性面での機械的性質の向上に有効に作用す ることも考えられる。この点に関して，炭化物の 析出は硬さの低下による靸性の向上はあっても低 下する結果は得られていないとする報告 ${ }^{14)}$ も る.しかし，䩗性に及ぼすマルテンサイト微細化 の効果については，炭化物析出による硬さの低下 や炭化物の粒界八の析出によるマイナス面も合わ せてさらに検討する必要があろう。また，焼入冷 却をおそくすることは $\gamma_{\mathrm{R}}$ 低減のための処理とし ての利用も考えられる.

以上のように, Ms 点の変化は炭化物析出に関 連する焼入性の相違を的確に表し，さらに, Ms 点 の高低によってマルテンサイトの形態や $\gamma_{\mathrm{R}}$ 量の 推察も可能である. 従って, 焼入性の改善を目的 とする新鋼種開発などのため, 多鋼種にわたって
焼入性を評価する場合には，この Ms 点による方 法は簡単でかつ有効な手段と考える.

\section{2 硬さに及ぼす焼入冷却速度の影響}

焼入冷却途中で炭化物が析出すると，その後の 冷却によって得られるマルテンサイトは低C，低 合金となり硬さは低下する。しかし，炭化物析出 はオーステナイトを不安定とし $\gamma_{\mathrm{R}}$ を減少させる ため、この点では硬さ上昇の因子ともなる， $\gamma_{\mathrm{R}}$ 量 は鋼の化学組成や焼入温度によって大きく異な る. Fig. 9 は1 050 $900^{\circ} \mathrm{C}$ の冷却速度の相違によ る $\gamma_{\mathrm{R}}$ の面積率の変化を示した図で, 鋼種, 冷却条 件によって $\gamma_{\mathrm{R}}(\%)$ がかなり異なることがわかる. このため, 焼入れあるいは低温での焼戻し状態で $\gamma_{\mathrm{R}}$ の存在がさけられない本実験鋼種のような場 合に, その硬さによって炭化物の析出状況を推察 


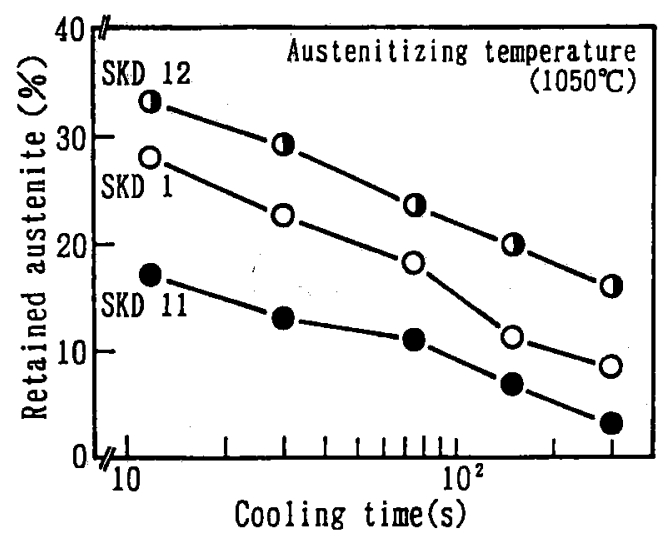

Fig. 9. Effect of time for cooling from $1050^{\circ} \mathrm{C}$ to $900^{\circ} \mathrm{C}$ on the amount of retained austenite.

することは異鋼種間での比較はもとより同一鋼種 においても容易でない.一方， $\gamma_{\mathrm{R}}$ の影響をなくす には，高温焼戻しによる硬さの比較もあるが，こ の場合も鋼種や焼入条件によって二次硬化現象の 相違，つまり，硬化の程度やピーク硬さが得られ る温度が異なることなど，一律に比較できない面 がある．また，繰返し焼戻しを必要とする場合も あり，最適条件を決定するためには，さらに別途 実験によるデー夕を要する。

\section{5. 結}

\section{言}

以上, 冷間ダイス鋼に関して, Ms 点による炭化 物析出に起因する焼入性の評価の可能性について 検討した。その結果を要約すると次のようになる。

（1）焼入冷却速度の減少に伴い，微細孷化物が オーステナイトの結晶粓界に析出し，さらに冷却 がおそくなると粒内にも析出する。

（2）焼入冾却途中で炭化物が析出すると, Ms 点は高温側に移行し, 得られるマルテンサイトは 微細化する。

（3）炭化物の析出について，焼入れあるいは焼 戻し硬さのみによって判断することは難しいとし た.

（4） Ms 点の変化と崖化物の析出はよく対応す る結果が得られたことより，Ms点によって炭化 物の析出程度が把握できるとした。

（5）炭化物の析出に基づく焼入性については,
Ms 点を指標とすれば簡単でかつ正確な評価がで きるとした。

\section{(文献)}

1) P.Leckie-Ewing and W.A.Jacobsen: Metall.Trans., 1(1970), 1427

2) 浅井武二, 山岸憲一郎, 辻淵清和：鉄と鋼, 59 (1973), S251

3）水野博司，伊藤一夫，常陸美朝，松田幸紀： 鉄と鋼，68（1982），S1453

4）水野博司，伊藤一夫，常陸美朝，松田幸紀： 鉄と鋼，68（1982），S1454

5）内田憲正：熱処理，29（1989），2

6）田村 庸，奥野利夫：材料とプロセス，4 (1991)， 1897

7）伊藤一夫，常陸美朝：電気製鋼，50（1979）, 181

8）上原紀興，並木邦夫，高橋国男：電気製鋼, 52 (1981)， 165

9）奥野利夫：鉄と鋼，69 (1983)，655

10）奥野利夫：鉄と鋼，69 (1983), 1676

11）中居則彦，小幡充男：鉄と鋼，77(1991)， 147

12）近藤邦夫，岡田康孝：材料とプロセス， 2 (1989), 864

13）川上哲, 朝日 均, 上野正勝：材料とプロ セス, 4 (1991)， 894

14）清永欣吾：特殊鋼，29（1980），11，28

15）広瀬之彦，山本誠司，板倉邦輔：熱処理， 33 (1993)，（No.3に揭載予定）

16) P.Leckie-Ewing : Metall Prog., 100 (1971), 2, 86

17）浅井武二, 山岸憲一郎, 辻淵清和：鉄と鋼, 59 (1973), S250

18）例之ば，西山善次：マルテンサイト変態（基 本編)，(1971)，219［丸善]

19）牧 正志，田村今男：日本金属学会会報, 13 (1973), 329

20）白橋忠臣，楓 博：特殊鋼，41（1992），12, 7

21）井口信洋, 横田清義：日本金属学会誌，39 (1975), 19

22）例之ば，佐藤知雄，本田 裕，西沢康二：鉄 と鋼，42 (1956), 1118 